\title{
Hubungan Penambahan Berat Badan Ibu Selama Hamil dengan Berat Badan Bayi Baru Lahir
}

\section{Intan Sari}

Akademi Kebidanan Budi Mulia Prabumulih

Informasi Artikel :

Diterima : 30 April 2021

Direvisi : 02 Mei 2021

Disetujui : 29 Mei 2021

Diterbitkan : 15 Juni 2021

*Korespondensi Penulis : intannadhifa215@gmail.com

\section{A B S T R A K}

Kenaikan berat badan ibu hamil bergantung pada perencanaan menu yang benar. Masukan gizi pada ibu hamil sangat menentukan kesehatannya dan janin yang dikandungnya. Janin sangat tergantung kepada ibunya untuk pernafasan, pertumbuhan, dan untuk melindunginya dari penyakit. Untuk mengetahui hubungan penambahan berat badan ibu selama hamil dengan berat badan bayi baru lahir di Klinik Budi Mulia Medika. Jenis penelitian yang digunakan adalah penelitian yang bersifat explanatory research dengan pendekatan cross sectional dan melalui studi retrospektif. Penelitian dilakukan pada ibu yang mempunyai bayi kurang dari satu bulan di Kelurahan Sukajaya dengan populasi 35 ibu dan didapatkan jumlah sampel sebesar 35 responden. Penambahan berat badan ibu selama hamil sekitar $10-15 \mathrm{~kg}$ dan sebagian besar berat badan lahir pada bayi adalah sekitar $2.500-4.000$ gram. Hasil analisis statistik menunjukkan bahwa ada hubungan positif yang kuat dan signifikan antara penambahan berat badan ibu selama hamil dengan penambahan berat badan lahir pada bayi di Klinik Budi Mulia Medika ( $p$ value $=0,000$ ) dengan koefisien korelasi sebesar 0,643. Ada hubungan yang bermakna antara penambahan berat badan ibu selama hamil dengan berat badan bayi baru lahir di Klinik Budi Mulia Medika. Ibu hamil memeriksakan kehamilannya minimal 4x selama kehamilan ke tempat pelayanan kesehatan yang tersedia. Pemenuhan gizi selama kehamilan harus seimbang agar didapatkan penambahan berat badan selama hamil yang adekuat.

Kata kunci : Penambahan berat badan ibu selama hamil, berat badan bayi baru lahir

\section{ABSTRACT}

Pregnant women weight gain depends on proper menu planning. Nutritional input for pregnant women will determine their health and the fetus they are carrying. The fetus is very dependent on the mother for respiration, growth, and to protect it from disease. To determine the relationship between maternal weight gain during pregnancy and newborn body weight at the Budi Mulia Medika Clinic. This type of research is an explanatory research with a cross sectional approach and through a retrospective study. The study was conducted on mothers who have babies less than one month in Sukajaya Village with a population of 35 mothers and obtained a sample size of 35 respondents. Maternal weight gain during pregnancy is around 10-15 $\mathrm{kg}$ and most of the birth weight in infants is around 2,500-4,000 grams. The results of statistical analysis show that there is a strong and significant positive relationship between maternal weight gain during pregnancy and birth weight gain in infants at the Budi Mulia Medika Clinic ( $p$ value $=0.000)$ with a correlation coefficient of 0.643. There is a significant relationship between maternal weight gain during pregnancy and newborn weight at the Budi Mulia Medika Clinic. Pregnant women have their pregnancies checked at least 4 times 
during pregnancy to the available health services. The fulfillment of nutrition during pregnancy must be balanced in order to obtain adequate weight gain during pregnancy.

Keyword

\section{PENDAHULUAN}

Masa kehamilan adalah masa awal bagi pertumbuhan dan perkembangan bayi (Johnson,2014). Pertumbuhan dan perkembangan bayi dipengaruhi oleh faktor genetik dan faktor lingkungan. Faktor lingkungan secara garis besar dibagi menjadi faktor lingkungan pranatal yang berpengaruh terhadap tumbuh kembang janin mulai dari konsepsi sampai lahir salah satu diantaranya gizi ibu pada waktu hamil (Soetjiningsih, 2011).

Salah satu kebijakan pemerintah dalam usaha menurunkan Angka Kematian Ibu (AKI) melalui upaya "Safe Motherhood" dimana sebagai pilar kedua yaitu akses terhadap pelayanan antenatal (Sarwono, 2012). Pelayanan antenatal adalah pelayanan yang diberikan kepada ibu hamil secara berkala untuk menjaga kesehatan ibu dan janinnya (Depkes, 2018). Tujuan utama pelayanan antenatal adalah untuk memfasilitasi hasil yang sehat dan positif bagi ibu maupun bayinya (Pusdiknakes, 2020). Dengan adanya pelayanan / asuhan antenatal atau ANC diharapkan kemajuan kehamilan dapat dipantau dalam setiap kunjungannya selama kehamilan (Pusdiknakes, 2013).

Ada beberapa cara yang dapat digunakan untuk mengetahui status gizi ibu hamil antara lain memantau pertumbuhan berat badan selama hamil dan mengukur LILA (Lubis, 2013). Apabila LILA kurang dari $23,5 \mathrm{~cm}$ atau di bagian merah pita LILA dapat dikategorikan menjadi kurang energi kronik (Supariasa, 2012). Sedangkan status gizi ibu hamil pada waktu pembuahan dan selama hamil dapat mempengaruhi pertumbuhan janin yang sedang dikandung (Huliana, 2011).

Seorang ibu yang sedang hamil mengalami kenaikan berat badan antara 6,5 sampai $16,5 \mathrm{~kg}$ selama hamil atau terjadi kenaikan berat badan sekitar $1 / 2 \mathrm{~kg}$ per minggunya. Penambahan berat badan pada trimester I $\pm 1 \mathrm{~kg}$, pada trimester II adalah \pm $5 \mathrm{~kg}$, pada trimester III adalah $\pm 5,5 \mathrm{~kg}$ (Manuaba, 1998). Berat badan ibu hamil yang dianjurkan tergantung dari berat badan sebelum kehamilan karena hal ini penting bagi kesehatan ibu dan bayi. Kenaikan berat badan ideal ibu hamil $7 \mathrm{~kg}$ untuk ibu yang gemuk dan $12,5 \mathrm{~kg}$ untuk ibu yang tidak gemuk (Huliana, 2011).

Kenaikan berat badan ibu hamil bergantung pada perencanaan menu yang benar. Masukan gizi pada ibu hamil sangat menentukan kesehatannya dan janin yang dikandungnya. Janin sangat tergantung kepada ibunya untuk pernafasan, pertumbuhan, dan untuk melindunginya dari penyakit. Kebutuhan gizi pada masa kehamilan berbeda pada masa sebelum hamil. Peningkatan gizi ibu hamil menurut Huliana yang dikutip dari Paath (2014) sebesar $50 \%$ karena dibutuhkan untuk pertumbuhan rahim, payudara, volume darah, plasenta, air ketuban dan pertumbuhan janin. Pertumbuhan janin membutuhkan sebesar $40 \%$ dari makanan yang dikonsumsi ibu, sedangkan yang $60 \%$ untuk memenuhi kebutuhan ibu. Apabila masukan gizi pada ibu hamil kurang maka kemungkinan akan terjadi gangguan dalam kehamilan, baik terhadap ibu maupun janin yang dikandungnya.

Faktor yang menentukan jumlah zat makanan yang harus diberikan agar kehamilannya berjalan lancar adalah berat badan yang lebih ataupun kurang daripada berat badan rata-rata untuk umur tertentu (Huliana, 2011). Jika berat badan sebelum hamil berlebih akan mempunyai risiko diabetes mellitus gestasional atau terjadinya pre eklamsi (Suririnah, 2015). Ibu dengan diabetes mellitus gestasional sekitar $40 \%$ akan melahirkan bayi dengan berat badan berlebihan pada semua usia kehamilan 
(Saifuddin, 2012). Sebaliknya jika berat badan kurang sebelum hamil akan menghambat pertumbuhan janin dalam kandungan yang pada akhirnya akan terjadi berat badan lahir rendah (BBLR) atau terjadi gangguan kehamilan lain (Suririnah, 2015).

Di Kecamatan Sukarami khususnya di Klinik Bersalin Budi Mulia Medika jumlah rata-rata persalinan pada tahun 2020 sebanyak $10 \mathrm{ibu}$ bersalin perbulan. Jumlah rata-rata ibu bersalin selama 3 bulan terakhir yaitu 9 orang perbulan yang meliputi Februari sebanyak 12 ibu bersalin, Maret sebanyak 7 ibu bersalin dan April sebanyak 8 ibu bersalin dengan berat badan lahir tertinggi adalah normal (2500-3600). Namun pada bulan Mei terdapat dua neonatus yang mempunyai April badan lahir > 2500 gram.

Kekurangan gizi selama kehamilan dapat memberikan efek yang merugikan baik bagi ibu maupun bagi bayi yang dikandungnya. Kekurangan energi dan protein selama kehamilan akan mengakibatkan ibu mengalami anemia (Moore, 2018). Dari suatu penelitian diketahui bahwa risiko melahirkan dengan BBLR atau memperoleh bayi dengan gangguan pertumbuhan dan perkembangan otak lebih tinggi pada ibu hamil yang kekurangan energi dan protein (William dan Rahardja, 2018).

Berdasarkan pernyataan-pernyataan yang telah diuraikan sebelumnya dan teoriteori yang ada, serta berdasarkan salah satu peran dosen / bidan yaitu sebagai peneliti, maka penulis tertarik untuk menyusun karya tulis ilmiah tentang "Hubungan Penambahan Berat Badan Ibu Selama Hamil dengan Berat Badan Bayi Baru Lahir di Klinik Budi Mulia Medika".

\section{METODE PENELITIAN}

Jenis penelitian yang akan dilakukan adalah penelitian menggunakan metode survei analitik atau biasa disebut explanatory research yaitu penelitian yang bertujuan untuk memberikan penjelasan tentang sifat sifat populasi dari daerah penelitian. Dalam hal ini analisa yang digunakan adalah analisa korelasi atau hubungan antara variabel bebas dengan variabel terikat (Notoatmodjo, 2015).

Rancangan penelitian yang sesuai adalah penelitian dengan pendekatan cross sectional merupakan penelitian yang dilakukan dalam waktu bersamaan pada semua variabel penelitian dan melalui studi retrospektif yaitu pengumpulan data dimulai dari efek atau akibat yang telah terjadi, kemudian dari efek tersebut ditelusuri penyebabnya atau variabel-variabel yang mempengaruhi akibat tersebut (Notoatmodjo, 2015). Penelitian ini dilakukan pada bulan Februari - April tahun 2021 di Klinik Budi Mulia Medika.

Populasi dalam penelitian ini adalah semua ibu yang bersalin di Klinik Budi Mulia Medika yaitu 35 ibu. Dalam teknik pengambilan sampel penulis menggunakan metode total sampling / sampel jenuh yaitu pengambilan sampel dari semua populasi yang ada ( Sugiyono, 2015).

Dalam penelitian ini data yang dikumpulkan berasal dari : Data primer yaitu data yang diperoleh secara langsung dari responden dengan wawancara menggunakan isian singkat berisikan pertanyaan tentang berat badan ibu sebelum hamil dan selama hamil (TM I, II, III) serta berat badan bayi pada waktu dilahirkan. Data sekunder yaitu data yang diperoleh dari kohort ibu hamil (KMS).

Instrumen penelitian dari penelitian ini adalah isian singkat yang diisi peneliti sendiri dari data kohort ibu hamil (KMS). Dalam hal ini jenis pertanyaan yang digunakan adalah open ended question yaitu pertanyaan terbuka tanpa adanya kategori pilihan jawaban tertentu pada pertanyaan tersebut (Nursalam, 2013).

\section{HASIL PENELITIAN}

Sesuai dengan populasi yang telah ditetapkan pada penelitian ini didapatkan 35 responden yang ikut berpartisipasi. Dari penelitian tentang penambahan berat badan ibu selama hamil dan berat badan lahir pada bayi di Klinik Budi Mulia Medika didapatkan hasil : 
Jurnal Kebidanan : Jurnal Medical Science Ilmu Kesehatan Akademi Kebidanan Budi Mulia Palembang Volume.11 No.1, Juni 2021

Available online http://journal.budimulia.ac.id/

1. Penambahan berat badan ibu selama hamil

Tabel 1 Distribusi frekuensi penambahan berat badan ibu selama hamil di Klinik Budi Mulia Medika

\begin{tabular}{ccc}
\hline $\begin{array}{c}\text { Penambahan berat Jumlah } \\
\text { badan selama } \\
\text { hamil }\end{array}$ & $\begin{array}{c}\text { Prosentase } \\
(\mathbf{\%})\end{array}$ \\
\hline Baik & 32 & $91,4 \%$ \\
Tidak & 3 & $8,6 \%$ \\
\hline Total & $\mathbf{3 5}$ & $\mathbf{1 0 0} \%$ \\
\hline
\end{tabular}

Dari tabel 1 diketahui bahwa sebagian besar ibu hamil memiliki penambahan berat badan baik, ini dapat dilihat dari sebanyak 32 ibu yang memiliki penambahan berat badan baik. Berikutnya ibu hamil yang mempunyai penambahan berat badan tidak baik sebanyak 3 orang.

\section{Berat Badan Bayi Baru Lahir di Klinik Budi Mulia Medika}

Tabel 2 Distribusi frekuensi berat badan bayi baru lahir di Klinik Budi Mulia Medika

\begin{tabular}{ccc}
\hline BB BBL & Jumlah (n) & Prosentase (\%) \\
\hline KMK & 3 & $8,6 \%$ \\
SMK & 30 & $94,3 \%$ \\
BMK & 2 & $5,7 \%$ \\
\hline Total & $\mathbf{3 5}$ & $\mathbf{1 0 0} \%$ \\
\hline
\end{tabular}

Dari tabel 2 diketahui bahwa sebagian besar bayi mempunyai berat badan lahir sesuai dengan umur kehamilan sebanyak 30 bayi. Bayi yang mempunyai berat badan lahir kecil menurut umur kehamilan sebanyak 3 bayi dan sisanya 2 bayi yang memiliki berat badan besar menurut umur kehamilan.

3. Hubungan antara penambahan berat badan ibu selama hamil dengan berat badan bayi baru lahir di Klinik Budi Mulia Medika

Tabel 3 Distribusi frekuensi hubungan penambahan berat badan selama hamil dengan berat badan bayi baru lahir di Klinik Budi Mulia Medika

\begin{tabular}{cccccc}
\hline $\begin{array}{c}\text { Penambahan } \\
\text { berat badan ibu } \\
\text { selama hamil }\end{array}$ & KMK & SMK & BMK & Total & Prosentase \\
\cline { 2 - 5 } Baik & 0 & 30 & 2 & 32 & $91,4 \%$ \\
Tidak & 3 & 0 & 0 & 3 & $8,6 \%$ \\
Total & 3 & 30 & 2 & 35 & $100 \%$ \\
\hline Prosentase & $\mathbf{8 , 6} \%$ & $\mathbf{8 5 , 7} \%$ & $\mathbf{5 , 7} \%$ & $\mathbf{1 0 0} \%$ & \\
\hline
\end{tabular}

Berdasarkan tabel 3 dari 35 responden ternyata penambahan berat badan ibu selama hamil yang paling banyak adalah baik yaitu sebanyak 32 responden $(91,4 \%)$ dan dari jumlah tersebut kondisi BB BBLnya adalah SMK yaitu sebanyak 30 bayi $(85,7 \%)$ dan dengan kondisi BB BBL BMK ada 2 bayi $(5,7 \%)$. Responden yang memiliki penambahan berat badan selama hamil tidak baik sebanyak 3 responden $(8,6 \%)$ dengan kondisi BB BBL KMK yaitu sebanyak 3 bayi $(8,6 \%)$.
Berdasarkan hasil analisa statistik dengan uji Spearman Rank, didapatkan nilai $\mathrm{p}=0,000$ dengan $\alpha=0,05$ sehingga $\mathrm{p}<\alpha$ maka dapat dikatakan bahwa terdapat hubungan antara status gizi ibu hamil dengan berat badan bayi baru lahir dan berarti $\mathrm{Ha}$ diterima.

\section{PEMBAHASAN}

Hasil penelitian ini secara umum sudah menjawab pertanyaan penelitian dan kerangka konsep. Tujuan umum penelitian 
ini adalah untuk mengetahui hubungan penambahan berat badan selama hamil dengan berat badan bayi baru lahir di Klinik Budi Mulia Medika Hasil penelitian tersebut kemudian dilakukan pembahasan dengan melihat literatur review.

\section{Identifikasi Penambahan Berat Badan Ibu Selama Hamil di Klinik Budi Mulia Medika.}

Pada tabel 1 dan perhitungan secara statistik diperoleh hasil mayoritas responden memiliki penambahan berat badan selama hamil baik yaitu sebanyak 32 ibu hamil, berikutnya yang mempunyai penambahan berat badan tidak baik sebanyak 3 ibu.

Penelitian ini bermaksud untuk mengidentifikasi penambahan berat badan ibu selama hamil di Klinik Budi Mulia Medika. Penambahan berat badan ibu selama hamil erat hubungannya dengan perubahan metabolisme tubuh ibu selama hamil (Manuaba,2019).Sebagian besar penambahan berat badan selama hamil dihubungkan dengan uterus dan isinya termasuk janin, payudara dan penambahan volume darah serta cairan ekstraseluler ekstravasikuler (Cunningham, 2016). Untuk itu telah diambil sampel sebesar 35 ibu dengan bayi kurang dari 1 bulan (neonatus) dari 35 populasi (total sampling).

Semua sampel yang diteliti didapatkan penambahan berat badan selama hamil sekitar $10-15 \mathrm{~kg}$, menurut teori berat badan ibu hamil akan bertambah antara 6,5 sampai $16,5 \mathrm{~kg}$ selama hamil atau terjadi kenaikan berat badan sekitar $1 / 2 \mathrm{~kg}$ per minggunya. Penambahan berat badan pada trimester $\mathrm{I} \pm 1$ $\mathrm{kg}$, pada trimester II adalah $\pm 5 \mathrm{~kg}$, pada trimester III adalah $\pm 5,5 \mathrm{~kg}$ (Manuaba, 2018). Hal ini berarti berdasarkan hasil penelitian penambahan berat badan ibu di Desa Bakalan selama hamil masih dalam keadaan baik.

\section{Identifikasi Berat Badan Bayi Baru Lahir di Klinik Budi Mulia Medika.}

Berdasarkan hasil pengolahan data mengenai berat badan bayi baru lahir didapatkan hasil sebagian besar bayi berat badan bayi pada waktu lahir sudah sesuai dengan umur kehamilan yaitu sebanyak 30 bayi, berikutnya 3 bayi mempunyai berat badan lahir kecil menurut umur kehamilan dan 2 bayi yang memiliki berat badan lahir besar menurut umur kehamilan.

Adapun berat badan lahir pada bayi dari hasil penelitian didapatkan sekitar 2.300 - 4.000 gram. Hal ini berarti berdasarkan hasil penelitian dibandingkan dengan berat badan lahir normal, berat badan lahir pada bayi di Desa Bakalan masih ada yang berlebihan sekitar 400 gram dan yang kurang sekitar 200 gram. Untuk berat badan bayi baru lahir lebih dari 4.000 gram dimungkinkan karena makrosomia dan kurang dari 2.500 gram (BBLR) dikarenakan retardasi pertumbuhan intra uterin (Cunningham, 2006). Namun, sebagian besar bayi yang diteliti mempunyai berat badan lahir antara 2.500-3.600 gram serta sesuai dengan umur kehamilan. Hal ini sesuai dengan yang dinyatakan Hasuki (2006) bahwa normalnya berat badan bayi baru lahir harus mencapai $2.500-3.600$ gram. Hal ini berarti berdasarkan hasil penelitian berat badan bayi baru lahir di Desa Bakalan masih dalam keadaan normal sesuai dengan umur kehamilan.

\section{Hubungan Penambahan Berat Badan Ibu Selama Hamil dengan Berat Badan Bayi Baru Lahir}

Korelasi merupakan angka yang menunjukkan arah dan kuatnya hubungan antar dua variabel atau lebih. Arah dinyatakan dalam bentuk hubungan positif atau negatif, sedangkan kuatnya hubungan dinyatakan dalam besarnya koefisien korelasi (Sugiyono, 2005). Korelasi spearman rank yaitu teknik korelasi yang digunakan untuk mencari hubungan dan membuktikan hipotesis hubungan dua variabel bila data berbentuk ordinal dan sumber data dapat berasal dari sumber yang tidak sama serta tidak harus terdistribusi normal (Sugiyono, 2005). 
Hasil analisa statistik dengan uji Spearman Rank, didapatkan besar koefisien korelasi yaitu 0,643 dengan nilai $\mathrm{p}=0,000$ dan pada tingkat signifikan 5\% $(\alpha=0,05)$ sehingga $\mathrm{p}<\alpha$, jadi dapat disimpulkan terdapat hubungan positif yang kuat dan signifikan antara penambahan berat badan ibu selama hamil dengan berat badan bayi baru lahir di Klinik Budi Mulia Medika.

Dari hasil perhitungan, koefisien korelasi dari hubungan penambahan berat badan ibu selama hamil dengan berat badan bayi baru lahir di Klinik Budi Mulia Medika adalah 0,643 yang berarti secara statistik menunjukkan korelasi yang kuat (Sugiyono, 2015) dengan arah korelasi positif.

Berdasarkan hasil uji korelasi spearman rank dan garis linear pada diagram tebar, maka dapat dikatakan bahwa terdapat hubungan antara penambahan berat badan ibu selama hamil dengan berat badan bayi baru lahir yang artinya semakin besar penambahan berat badan ibu selama hamil maka semakin besar pula kondisi berat badan bayi baru lahir dan sebaliknya semakin kurang penambahan berat badan ibu selama hamil maka semakin kurang kondisi berat badan bayi baru lahir. Dari hasil penelitian terdapat beberapa penambahan berat badan ibu selama hamil yang tidak sesuai dengan berat badan lahir pada bayi, hal ini kemungkinan dikarenakan adanya variabel variabel pengganggu yang berupa pola konsumsi gizi ibu hamil yang berbeda, umur kehamilan ibu saat melahirkan bayinya dan faktor-faktor lain yang dapat mempengaruhi kedua variabel tersebut (Manuaba, 2018).

Berat badan bayi baru lahir ditentukan oleh (disamping faktor genetis) status gizi janin. Status gizi janin ditentukan antara lain oleh status gizi ibu waktu melahirkan dan keadaan ini dipengaruhi pula oleh status gizi ibu pada waktu konsepsi. Ibu harus mendapat zat gizi yang cukup selama hamil. Kecukupan zat gizi selama hamil baru dapat dipantau melalui parameter keadaan kesehatan ibu melalui penambahan berat badan ibu selama hamil dan berat lahir1 janin (Arisman, 2014).
Meskipun baku penilaian status gizi wanita yang tidak hamil tidak dapat diaplikasikan pada wanita hamil, perubahan fisiologis selama hamil dapat digunakan sebagai petunjuk. Berat badan rendah sebelum konsepsi, serta pertambahan berat yang tidak adekuat merupakan penilaian langsung yang dapat digunakan untuk memperkirakan laju pertumbuhan janin. Berat lahir berkorelasi positif dengan pertambahan berat total selama hamil (Arisman, 2014). Hal ini sesuai dengan hasil penelitian yang telah dilakukan di Klinik Budi Mulia Medika, yaitu ada hubungan yang bermakna antara penambahan berat badan ibu selama hamil dengan berat badan bayi baru lahir.

\section{KESIMPULAN}

Berdasarkan data hasil penelitian hubungan penambahan berat badan ibu selama hamil dengan berat badan bayi baru lahir di Klinik Budi Mulia Medika, kemudian dianalisa dan dapat ditarik kesimpulan sebagai berikut : Dari hasil penelitian penambahan berat badan selama hamil cukup baik. Hal ini dapat dilihat dari data penambahan berat badan ibu selama hamil masih dalam keadaan baik. Dari hasil penelitian didapatkan berat badan lahir pada bayi sebagian besar adalah normal sesuai umur kehamilan. Ada hubungan yang bermakna antara penambahan berat badan ibu selama hamil dengan berat badan bayi baru lahir di Klinik Budi Mulia Medika dengan korelasi yang kuat dan arah korelasinya positif, jadi semakin besar penambahan berat badan ibu selama hamil semakin besar pula berat badan bayi baru lahir di Klinik Budi Mulia Medika.

\section{SARAN}

1. Bagi tenaga kesehatan khususnya bidan desa diharapkan dapat mendukung sarana prasarana kesehatan dengan pemberian pelayanan antenatal secara lengkap terutama dengan pemeriksaan penambahan berat badan dan pemberian 
penyuluhan atau konseling tentang kecukupan gizi seimbang pada ibu hamil dan bayi baru lahir.

2. Bagi masyarakat setempat agar dapat meningkatkan peran serta masyarakat terutama dapat memotivasi ibu hamil agar memeriksakan kesehatan ke tempat pelayanan kesehatan yang tersedia serta dapat mendukung pemenuhan gizi yang seimbang bagi ibu hamil.

3. Bagi peneliti lain sebaiknya dilakukan juga penelitian lagi tentang faktor - faktor lain yang mempengaruhi status gizi ibu hamil yang dalam hal ini penambahan berat badan selama hamil dan berat badan bayi baru lahir, misalnya faktor pola konsumsi gizi dan faktor kehamilan.

\section{DAFTAR PUSTAKA}

Alimul, A. (2013) Riset Keperawatan dan Teknik Penulisan Ilmiah. Jakarta : Penerbit Salemba Medika.

Arisman. (2014) Buku Ajar Ilmu Gizi : Gizi Dalam Daur Kehidupan. Jakarta : EGC.

Azwar, A. (2013) Metodologi Pendekatan Praktek Kedokteran dan Kesehatan. Jakarta : Bina Rupa Aksara.

Budjang, R.F. (2012) Ilmu Kebidanan. Jakarta : Yayasan Bina Pustaka Sarwono Prawirohardjo.

Cunningham, F.G. (2016) Obstetri Williams Volume 1. Edisi 21. Huriawati Hartanto. ed. Jakarta : EGC.

Eisenberg, A. (2019) Makanan : Apa Yang Anda Butuhkan Selama Kehamilan. Jakarta : Arcan.

Hacker, N.F. (2011) Essensial Obstetri dan Ginekologi. Jakarta : Hipokrates.
Hasuki, I. (2016) Bayi Kurus Berarti Kurang Gizi? [Internet]. Jakarta : BKKBN. Tersedia dalam http://www.bkkbn.go.id/article_detail.p hp [Diakses 28 Maret 2021]

Huliana, M. (2011) Panduan Menjalani Kehamilan Sehat. Jakarta : Puspa Swara.

Kompas. (2013) Inisiatif Global Turunkan Angka Kematian Ibu [Internet]. Jakarta : Kompas. Tersedia dalam http://www.kompas.com/kompascetak/0305/03/iptek.htm [Diakses 12 April 2021]

(2013) Prioritas pada Penurunan Angka Kematian Ibu dan Bayi [Internet]. Jakarta : Kompas. Tersedia dalam

http://www.kompas.com/kompascetak/0705/05/fokus.htm [Diakses 12 April 2021]

(2013) Survei Demografi dan Kesehatan Indonesia 2003 Angka Kematian Turun [Internet]. Jakarta : Kompas. Tersedia dalam http://www.kompas.com/kompascetak/0312/19/iptek.htm [Diakses 12 April 2021]

Manuaba, I.B.G. (2018) Ilmu Kebidanan, Penyakit Kandungan, dan Keluarga Berencana. Jakarta : EGC.

Marjono, A.B. (2018) Kelainan Pada Lamanya Kehamilan [Internet]. Jakarta : Fakultas Kedokteran UI. Tersedia dalam

http://www.geocities.com/Yosemite/Ra pids/1774.html [Diakses 12 April 2021]

(2019) Pemeriksaan Obstetri dan Asuhan Antenatal [Internet]. Jakarta : Fakultas Kedokteran Universitas Indonesia. Tersedia dalam : 
http://www.geocities.com/Yosemite/Ra pids/1774.html [Diakses 12 April 2021]

. (2019) Pengantar Perinatologi [Internet]. Jakarta : Fakultas Kedokteran Universitas Indonesia. Tersedia dalam : http://www.geocities.com/Yosemite/Ra pids/1774.html [Diakses 12 April 2021]

(2019) Perubahan Anatomi dan Fisiologi Wanita Hamil [Internet]. Jakarta : Fakultas Kedokteran Universitas Indonesia. Tersedia dalam : http://www.geocities.com/Yosemite/Ra pids/1774.html [Diakses 12 April 2021]

Mochtar, R. (2018) Sinopsis Obstetri : Obstetri Fisiologi, Obstetri Patologi. Jakarta : EGC.

Moehji, S. (2013) Ilmu Gizi. Jakarta : Papas Sinanti.

Moore, M.C. (2018) Buku Pedoman Terapi Diet dan Nutrisi. Jakarta : Hipokrates.

Notoatmodjo, S. (2015) Metodologi Penelitian Kesehatan. Jakarta : PT Rineka Cipta.

Nursalam. (2013) Konsep dan Penerapan Metodologi Penelitian Ilmu Keperawatan : Pedoman Skripsi, Tesis dan Instrumen Penelitian Keperawatan. Jakarta : Penerbit Salemba Medika.

Paath, E.F. (2014) Gizi Dalam Kesehatan Reproduksi. Jakarta : EGC.

Pusdiknakes. (2011) Buku 2 : Asuhan Antenatal. Jakarta : Penerbit Pusdiknakes-WHO-JHPIEGO.
Ramaiah, S. (2015) Gaya Hidup Di Masa Hamil. Jakarta : PT Bhuana Ilmu Populer.

Rusepno, H. (2015) Buku Kuliah 3 Ilmu Kesehatan Anak. Jakarta : Percetakan Info Media.

Saifudin, A.B. (2012) Buku Acuan Nasional Pelayanan Kesehatan Anak Maternal dan Neonatal. Jakarta : Yayasan Bina Pustaka Sarwono Prawirohardjo.

Salmah. (2016) Asuhan Kebidanan Antental. Monica Ester. ed. Jakarta : EGC.

Sugiyono. (2015) Statistik untuk Penelitian. Bandung : C.V Alfabeta.

Supariasa. (2010) Ilmu Gizi. Jakarta : EGC.

Suririnah. (2015) Berapa Kenaikan Berat Badan yang Sebaiknya Selama Kehamilan? [Internet]. Jakarta : Info Ibu. Tersedia dalam : http://www.infoibu.com/mod.php [Diakses 28 Maret 2021]

Tara, E. (2014) Buku Pintar Kesehatan Kehamilan. Jakarta : Ladang Pustaka dan Inti Media. 
